\title{
DISTRIBUTION OF THE ANTI-GAMMA GLOBULIN FACTORS IN THE SYNOVIAL MEMBRANE AND OTHER TISSUES IN VARIOUS DISEASES*
}

BY

\author{
LORENZO BONOMO, ALFREDO TURSI, AND UGO GILLARDI \\ From the Institute of Clinical Medicine, University of Bari Medical School, Bari (Italy) \\ (Director: Prof. V. Chini)
}

It is well established that the synovial membrane represents one of the major sites of the formation of anti-gamma globulin factors (AGGF) $\dagger$ in rheumatoid arthritis (RA) (Mellors, Heimer, Corcos, and Korngold, 1959; McCormick, 1963).

During the examination of a number of synovial specimens obtained from cases of RA we were interested to observe the different patterns produced by the specific fluorescence due to AGGF.

This paper describes these findings and also the concentration of AGGF in other tissues, namely the bone marrow and the liver, in patients with diseases primarily involving these tissues, in all of whom circulating AGGF were present. It was our purpose to look for differences in the percentage of AGGFcontaining cells in these tissues in relationship to the primary pathological process.

\section{Material and Methods}

Synovium.-Specimens of synovial membrane were obtained by needle biopsy of the knee from 43 patients with RA and eight with various other diseases-liver disorder (3), Waldenström's macroglobulinaemia (3), polyarteritis nodosa (1), macroglobulinaemia (1). All those with RA had had the disease for more than a year, and most of them for several years. Sterile saline (approximately $100 \mathrm{ml}$.) was injected into the synovial cavity through the suprapatellar pouch, until the joint became swollen and hard. If synovial effusion was present, the fluid was withdrawn before the saline was injected. The biopsy specimen was obtained by inserting the Polley-Bickel needle into the lateral aspect of the knee 1 to $2 \mathrm{~cm}$. from the external corner of the patella, along its superior margin. When almost all the saline had been withdrawn, the cutting edge of the needle moved easily and as a rule several fragments of synovial tissue could be obtained.

\footnotetext{
*This work was supported in part by the Consiglio Nazionale delle Ricerche (Gruppo Immunologia), Rome, Italy. A preliminary report was given at the Symposium on Immunology, International Congress of Rheumatic Diseases, Mar del Plata, 1965.

In this paper the terms anti-gamma globulin factors and rheumatoid factors are used interchangeably.
}

Liver.-Eighteen liver specimens were obtained with a Menghini biopsy needle from eight cases of liver disease (cirrhosis (4), infective hepatitis (3), Banti syndrome ì (1)), seven of RA, and three of Waldenström's macro- $\vec{N}$ globulinaemia. The tissues were quick frozen at $\mathrm{N}$ $-70^{\circ} \mathrm{C}$. and later examined for the presence of AGGF 은 and other globulins.

Marrow.-Eleven bone marrow specimens were obtained by sternal puncture in three cases of macroglobulinaemia, five of RA, and three of liver disease (cirrhosis (2), infective hepatitis (1)). The smears wero fixed with cold acetone and then stained with fluorescen conjugates.

Anti-gamma globulin activity was demonstrated by reaction with aggregated human gamma globulin and/or pooled normal rabbit gamma globulin, both conjugated with fluorescein or tetramethyl-rhodamine isothiocyanate (B.B.L.-Baltimore). The rabbit gamma globulin was prepared by precipitation with $4 \cdot 1 \mathrm{M}$ ammonium sulphate; then it was heat-aggregated (at $63^{\circ} \mathrm{C}$. for 10 minutes) like the human gamma globulin.

Macroglobulin was demonstrated by reaction with a fluorescein-conjugated rabbit anti-human 19S antiserum as well as by the absence of specific fluorescence when the tissue sections were pre-treated with 2-mercaptoethanol. A strictly specific anti-IgG antiserum prepared in our laboratory was employed to detect the presence of $7 \mathrm{~S}$ IgG immunoglobulin in some biopsy specimens. A Leitz Laborlux microscope was used with a Philips $150 \cong$ mercury vapour light source. Details of the immuno- on fluorescence staining methods have been described elsewhere (Bonomo, Tursi, and Minerva, 1966).

The AGGF-containing cells were estimated by taking 2 the average in at least three medium-power $(\times 500) \stackrel{\leftrightarrow}{\subset}$ microscopic fields; usually from ten to fifteen fields were $\mathbb{D}$ counted for each slide. These criteria were used by ? Cohen, Ohta, Singer, and Popper (1960) and Bonomo and others (1966). 


\section{Results}

\section{Patterns of Fluorescence}

In the specimens of synovial membrane obtained from cases of RA, three patterns of fluorescence due to AGGF were observed: sparse, lymphoid, and vascular.

(1) Only sparse fluorescence was seen or aggregates of a variable number of AGGF-containing cells (mostly plasmocytes and lymphocytes) were scattered in the synovial tissue.

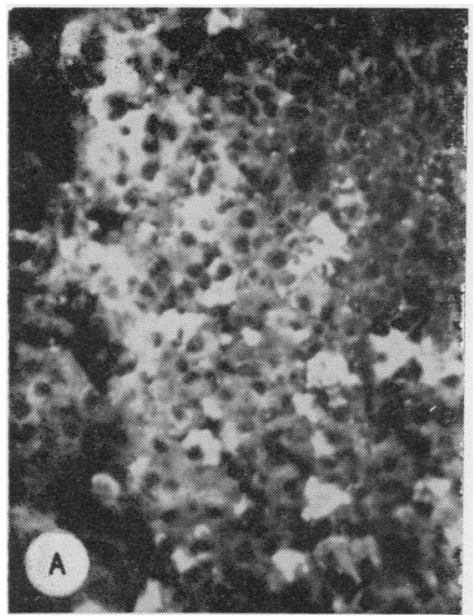

(A) Lymphoid infiltrate with areas rich in cells containing rheumatoid factor that stain brizhtly. (Stained by fluorescein-conjugated aggrezated human gamma globulin). $\times 250$
(2) The AGGF-containing cells produced a fluorescence with the aspect of lymphoid follicles (Fig. 1A). On staining with haematoxylin and eosin, the synovium appeared to be infiltrated with several such follicles (Fig. 1B).

Sometimes hypertrophic villi (Plate 1, overleaf) were seen to be rich in plasma cells containing AGGF.

(3) A conspicuous amount of fluorescence due to the AGGF was seen in the vessel walls and in cells scattered around the vessels (Fig. 2 A, C, D).

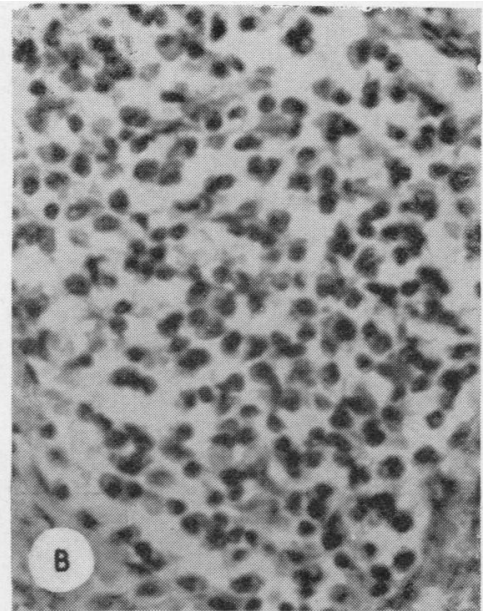

(B) Adjacent section of same specimen stained by hematoxylineosin. It shows lymphoid infiltrate in the synovium rich with plasma cells and lymphoid cells. $\times 250$.

Fig. 1.-Synovial membrane; rheumatoid arthritis.
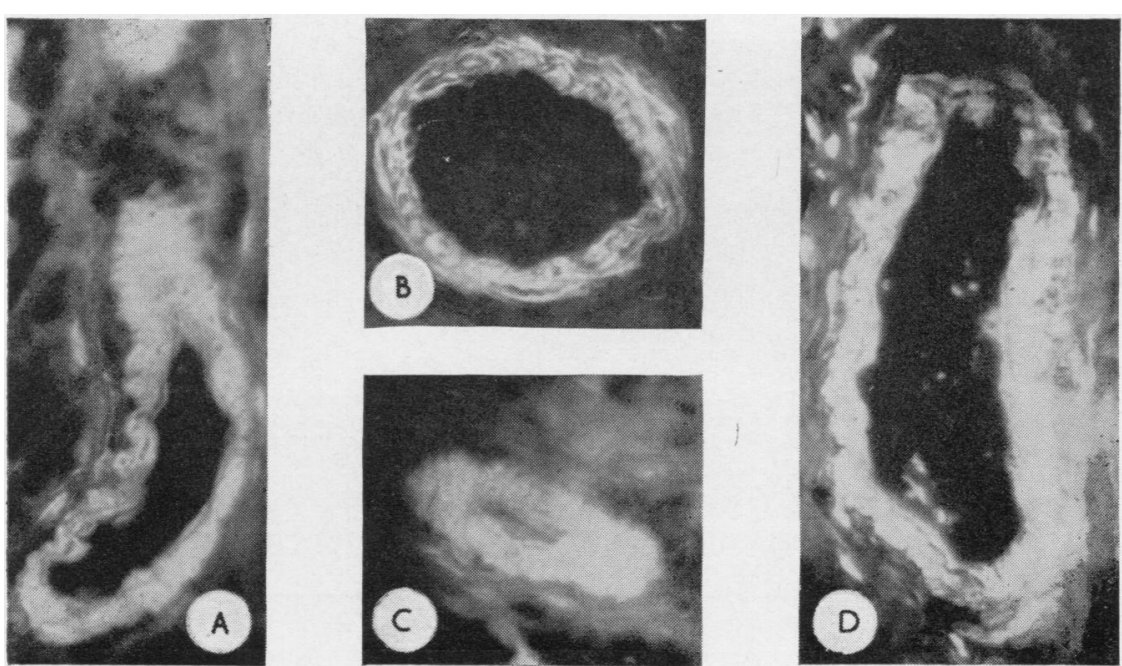

(A, C, D) Rheumatoid arthritis. Rheumatoid factor deposited in the vessel walls stains brightly with fluorescein conjugated agsregate. $\times 400$.

(B) Polyarteritis nodosa. Gamma globulin in the vessel walls stain brightly with fluorescein labelled anti-human gamma globulin antiserum. $\times 250$ 
A similar pattern of AGGF distribution has been described in two cases of "malignant" RA (Pernis, Ballabio, and Chiappino, 1963). In these specimens vasculitic alterations with perivascular infiltration of mono-nuclear cells were found when adjacent sections of the same biopsy specimen were stained with haematoxylin and eosin (Fig. 3).

In most cases with a vascular distribution of the AGGF there was no lymphoid infiltration and vice versa, so that these two patterns of synovial alteration seemed to be mutually exclusive.

In a few cases large non-cellular deposits were seen (Plate 2, opposite). Like the non-cellular deposits of immunoglobulins and complement described by Fish, Michael, Gewurz, and Good (1966), these may be due to destruction of phagocytic RA cells or plasma cells with release of the cytoplasmic content into the supporting tissue.

\section{Disease Activity and Patterns of AGGF}

The disease activity was graded from 0 to 3 on the basis of laboratory findings (erythrocyte sedimenta- tion rate, haemoglobin, serum protein levels), 꾸 radiological appearances (cartilage erosion, osteo- $\stackrel{\Phi}{\triangle}$ porosis), and clinical data (muscle atrophy, grip $\bar{\exists}$ strength, number of joints involved, analgesic 믕. tablets per day, functional capacity).

The relationship between the pattern of AGGF $\overrightarrow{\vec{\rho}}$ distribution and disease activity is shown in Table $\mathrm{I} ; \stackrel{?}{\circ}$ the disease was more severe and the titres of cir- $\frac{C}{0}$ culating AGGF tended to be higher in patients with a vascular pattern of AGGF distribution.

\section{Concentration of AGGF in Different Tissues}

In eleven cases it was possible to estimate this $\vec{\circ}$ concentration in bone marrow, liver, and synovial $\overrightarrow{\vec{\omega}}$ membrane. The AGGF appeared to be mostly concentrated in the sites primarily involved by the disease process, the synovial membrane in RA, the liver in liver disease, and the bone marrow in $-\mathrm{V}$ macroglobulinaemia (Table II, see p. 125).

All patients with AGGF in the bone marrow also $\vec{N}$ had circulating AGGF in the blood; this applied ${ }_{0}^{N}$ to cases of RA, liver cirrhosis, macroglobulinaemia, and chronic bronchitis. The AGGF-containing

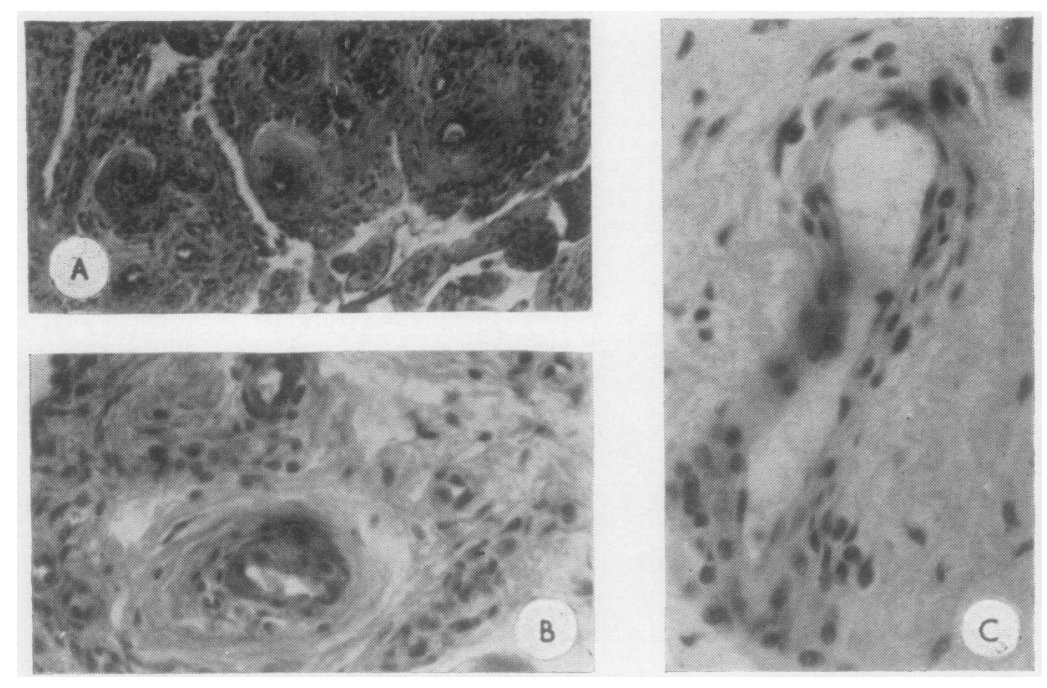

Fig. 3.-Synovial membrane. Rheumatoid arthritis.

(A, B, C) Vasculitic alterations in cases with deposition of rheumatoid factor in the vessel walls (Hematoxylin eosin; $A: \times 40$;

TABLE I

PATTERNS OF ANTI-GAMMA GLOBULIN FACTOR DISTRIBUTION IN SYNOVIAL MEMBRANE IN RHEUMATOID ARTHRITIS

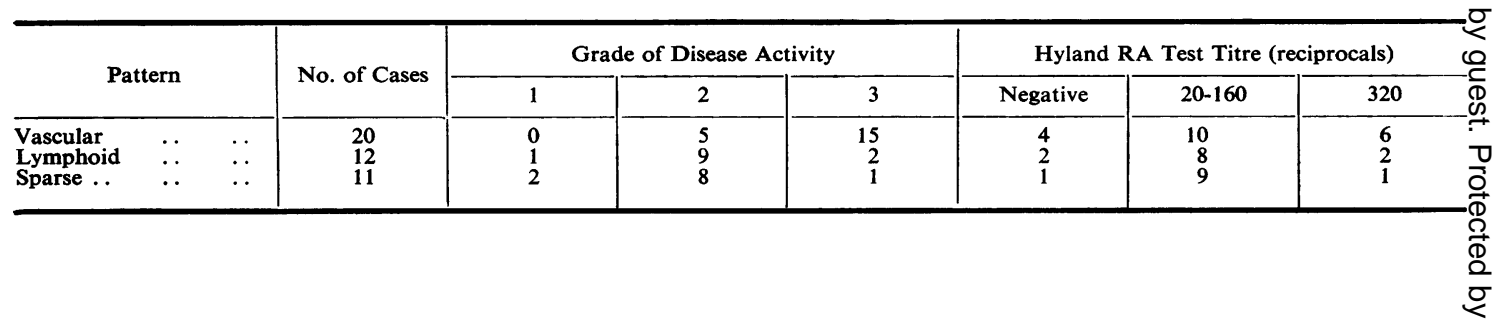



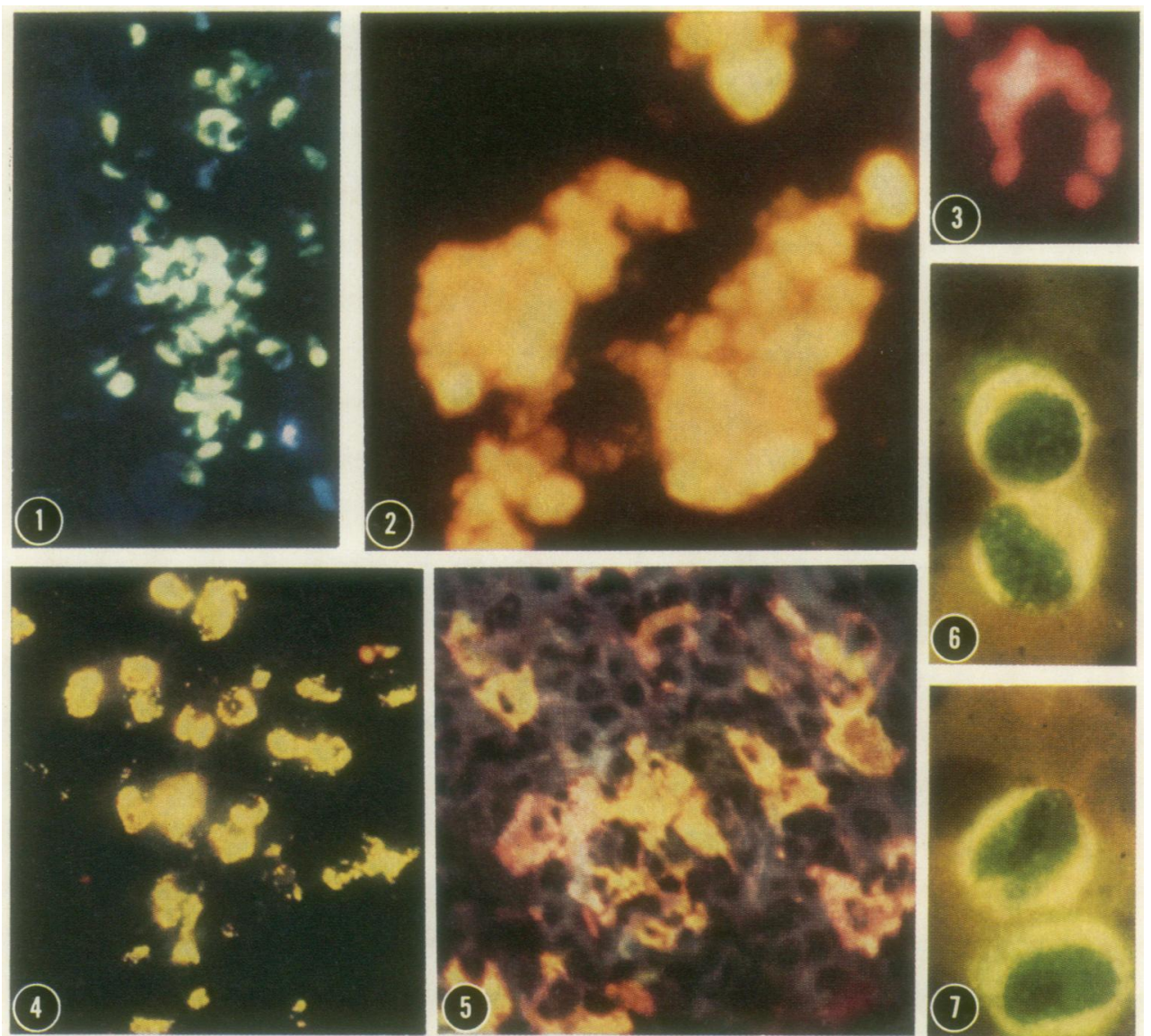
TABLE II

DISTRIBUTION OF ANTI-GAMMA GLOBULIN FACTORS IN VARIOUS TISSUES*

\begin{tabular}{|c|c|c|c|c|c|c|c|}
\hline Case No. & Diagnos & & & & Liver & Synovial Membrane & Bone Marrow \\
\hline $\begin{array}{l}1 \\
2 \\
3 \\
4 \\
5\end{array}$ & $\begin{array}{l}\text { Rheumatoid Arthritis } \\
\text { Rheumatoid Arthritis } \\
\text { Rheumatoid Arthritis } \\
\text { Rheumatoid Arthritis } \\
\text { Rheumatoid Arthritis }\end{array}$ & $\begin{array}{l}\cdots \\
\cdots \\
\cdots \\
\cdots\end{array}$ & $\begin{array}{l}\cdots \\
\cdots \\
\cdots \\
\cdots\end{array}$ & $\begin{array}{l}\cdots \\
\cdots \\
\cdots \\
\cdots\end{array}$ & $\begin{array}{l}+ \\
+ \\
+ \\
+ \\
+\end{array}$ & $\begin{array}{l}++ \\
++++ \\
++++ \\
+++ \\
++\end{array}$ & $\begin{array}{l}+ \\
+ \\
+ \\
+\end{array}$ \\
\hline $\begin{array}{l}6 \\
7 \\
8\end{array}$ & $\begin{array}{l}\text { Macroglobulinaemia } \\
\text { Macroglobulinaemia } \\
\text { Macroglobulinaemia }\end{array}$ & $\begin{array}{l}\cdots \\
\cdots \\
\cdots\end{array}$ & $\begin{array}{l}\cdots \\
\cdots \\
\cdots\end{array}$ & $\begin{array}{l}\cdots \\
\cdots \\
\cdots\end{array}$ & $\begin{array}{l}+ \\
+ \\
+\end{array}$ & \pm & $\begin{array}{c}+++ \\
+++ \\
++++\end{array}$ \\
\hline $\begin{array}{r}9 \\
10\end{array}$ & $\begin{array}{l}\text { Cirrhosis of Liver } \\
\text { Cirrhosis of Liver }\end{array}$ & $\begin{array}{l}\cdots \\
\cdots\end{array}$ & $\begin{array}{l}\cdots \\
\cdots\end{array}$ & $\begin{array}{l}\cdots \\
\cdots\end{array}$ & $\begin{array}{c}+++ \\
++\end{array}$ & 二 & $\begin{array}{l}+ \\
+\end{array}$ \\
\hline 11 & Infective Hepatitis & $\cdots$ & $\cdots$ & $\cdots$ & +++ & 一 & + \\
\hline
\end{tabular}

*Estimated mean maximum anti-gamma globulin factor-containing cells in at least three high-power fields: + represents $2-3$ cells

$++t 10$ or more

cells were particularly numerous in cases of macroglobulinaemia with high titres of circulating AGGF (Fig. 4).

The mean percentage of AGGF-containing cells in the bone marrow was as follows:

Five cases of RA $2 \cdot 60$ per cent.

Three cases of macroglobulinaemia 20 per cent.

Three cases of liver disease 4.43 per cent.

AGGF werealso demonstrated in the lymphocytoid cells present in the sputum of a patient with chronic bronchitis in agreement with previous findings (Bonomo and Tursi, 1963).

\section{Results of Mixed Staining}

Certain sections from liver and synovial membrane specimens were treated with both aggregated human gamma globulin and rabbit gamma globulin, conjugated with fluorescein isothiocyanate and tetramethylrhodamine isothiocyanate respectively.

It has been found that some cells form a factor which combines either with the fluorescent aggregate or the fluorescent immune complex, while some cells react with both (Mellors, 1963; McCormick, 1963).

Synovium.-Specimens of synovial membrane from RA cases contained cells reacting with both
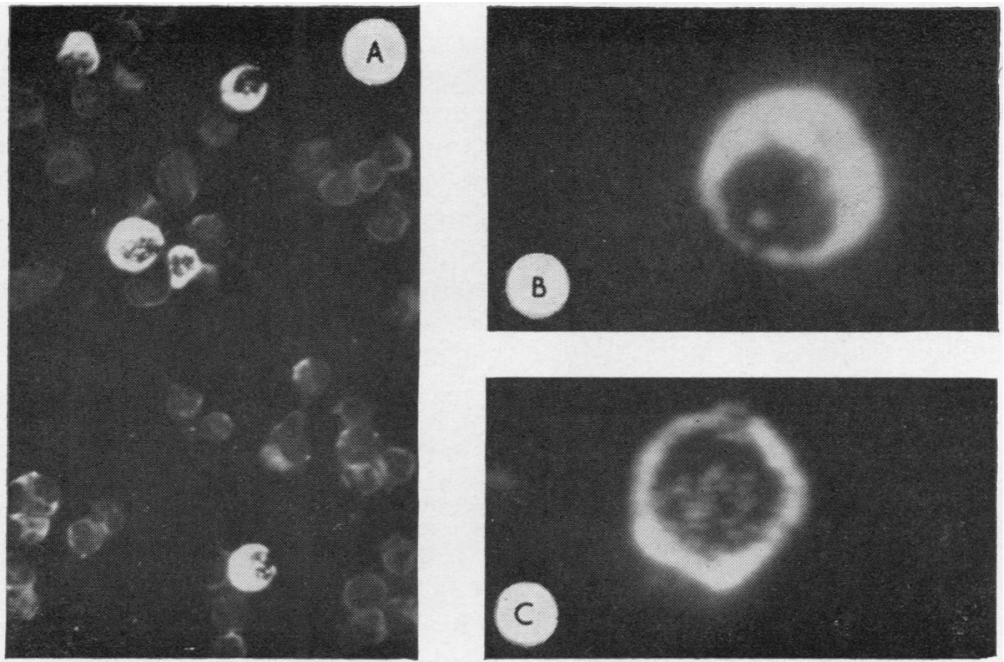

Fig. 4.- (A, B, C) Bone marrow. Waldenstrom macroglobulinemia. Plasma cells (B) and lymphoid cells (C) containing various amounts of antigamma globulin factor stain brightly with fluorescent aggregate $(\mathrm{A}: \times 250 ; \mathrm{B}, \mathrm{C}: \times 950)$. 
reactants (Plate 6,7 ) or mainly with rabbit gamma globulin (Plate 5, 9); cells reacting predominantly with human gamma globulin were less common (Plate 1).

Liver.-Specimens of liver tissue from cases of liver disease reacted mainly with human gamma globulin. Those from cases of RA reacted mainly with both reactants (Plate 4,8 ) or with the rabbit gamma globulin (Plate 3). Reaction with rabbit gamma globulin was very rarely found in specimens from patients with liver disease (Plate 10).

The presence of AGGF in liver tissue sections cannot be ascribed to phagocytosis alone, although AGGF were found frequently (but not exclusively) in Kupffer-like cells. AGGF-containing cells were indeed more numerous in the liver in patients with liver disease (particularly infectious hepatitis) than in patients with RA, although the levels of circulating AGGF were much higher in the latter.

\section{Fibrin in the Synovial Membrane}

In three specimens of synovial membrane from cases of RA the presence of fibrin was investigated by an anti-human fibrin antiserum conjugated with fluorescein isothiocyanate (Sylvana Co., Milburn, N.J.), and the presence of RF was evaluated by aggregated and rhodamine-conjugated human $F_{I I}$.

By this mixed procedure fibrin was found in the synovial lining. This agrees with previous findings (Kaplan, 1963), and much of the fibrin associated with RF showed a perivascular distribution.

\section{Discussion}

The existence of generalized immunological alterations not confined to the synovial membrane, lymph nodes, or spleen may be inferred in cases of RA from the distribution of the AGGF in various tissues and the behaviour of the immunologically competent cells (Bartfeld and Juliar, 1964; Malaguzzi-Valeri and Pipitone, 1965).

The distribution of AGGF in arthritic synovium conforms to the histological alterations in this tissue. A similar relationship has been observed in liver tissue (Bonomo and others, 1966). The presence of globulin is also related to the histopathological changes in arteritic lesions of the skin (Scott and Rowell, 1965) and synovium, as found in our case of polyarteritis nodosa (Fig. 2B).

Many recent findings (Dumonde and Glynn, 1962; Zvaifler and Pekin, 1963; Rodman, Williams, Bilka, and Müller-Eberhard, 1964; Fostiropoulos, Austen, and Bloch, 1965; Hollander, McCarty, Astorga, and Castro-Murillo, 1965; Astorga and Bollet, 1965; Ziff, 1965: Delbarre, Kahan, Amor, and Krassinine, 1966; Norton and Ziff, 1966) favouro the immunological interpretation of rheumatoid synovitis, as does the benign course of synovia $\bar{B}$ involvement in subjects with immunological insuffi므. ciency who develop RA (Good, 1963).

In particular, gamma globulin with antibody function deposited at the affected sites may repre온 sent the stimulus to the formation of AGGF Indeed $7 \mathrm{~S}$ gamma globulin, which may be thes source of aggregated gamma globulin, has beer found in the early lesions of rheumatoid synovitis (Kaplan, 1963).

Likewise, 7S IgG immunoglobulin, although inmuch smaller amounts, has been detected in syno $\vec{\omega}$ vium showing vasculitic and lymphoid alterations in our long-standing cases of RA.

The vascular deposition of AGGF may be caused $N$ by the presence in vasculitic lesions of the cells that produce these factors. On the other hand, aliquot of rheumatoid macroglobulin, particularly in cases with a high titre of circulating AGGF, may adhere to the vessel walls because of the nature of thez macroglobulin itself or because of a reaction witle globulin fractions or immunoglobulin complexes adhering thereto.

The synovial deposition of fibrin as well as $\$$ ts: association with rheumatoid factor in perivascutio areas may be related to the pathogenesis of rheuria toid synovitis. Indeed, an experimental model $\%$ arthritis has been achieved by the immunologicat reaction to fibrin (Dumonde and Glynn, 1962).

Various effects of the AGGF, mostly protective in $\overrightarrow{\vec{B}}$ nature, have recently been described. A localizing effect of RF on denatured gamma globulin has been found which may prevent severe systemic reactions? (Gough and Davis, 1966), phagocytosis of gamma globulin aggregates, and possible removal of abnormal globulins (Parker and Schmid, 1962 Williamson and Ling, 1965), blocking complement fixation (Zvaifler and Bloch, 1962; Gough and Davis윽 1966) and complement-dependent phenomena (Schmid and Roitt, 1965).

Therefore, the distribution of RF in the synovium? and particularly its vascular deposition may be due to a protective mechanism limiting the spread of lesions of which the original cause is still unknown?

It has been suggested that the vascular deposition of RF may contribute to rheumatoid vasculiti尺 (Epstein and Engleman, 1959; Scott, Hourihaneso Doyle, Steiner, Laws, Dixon, and Bywaters, 1961) but although present on the surface of the vascular endothelium of lymph nodes obtained from sero- -0 positive rheumatoid patients, it was not found in 
arteritic lesions of the digital vessels (Douglas, 1965).

Thrombosis and haemorrhage was produced in the vessels of the living rat mesentery by the intravenous injection of rheumatoid euglobulin preparations (Baum, Stastny, and Ziff, 1964).

The close association of the AGGF with histological lesions in various tissues suggests that they form part of the body's immune reaction to tissue damage.

These factors do not seem to be completely devoid of pathogenetic meaning. In fact they appear to be an obligatory requirement of rheumatoid synovitis (Hollander, Fudenberg, Rawson, Abelson, and Torralba, 1966); furthermore, the presence of conspicuous amounts of rheumatoid macroglobulin in the vasculitic lesions of the synovium still leaves unsolved the question of its possible involvement in their development.

\section{Summary}

In rheumatoid arthritis three patterns of distribution (sparse, lymphoid, and vascular) of anti-gamma globulin factors detected by immunofluorescence were observed in biopsy specimens of the synovial membrane. Such patterns reflected the histological alterations in the synovium.

The concentration of AGGF was greatest at the main sites of the disease process, i.e. the synovium in arthritis, the liver in liver disease, and the bone marrow in macroglobulinaemia. AGGF were also found in cells in the sputum of patients with chronic bronchitis.

Circulating AGGF were found in the blood of all these patients.

Mixed staining procedures with specific fluorochromes showed, in the synovium and liver of cases of arthritis, cells containing factors active against both aggregated human gamma globulin and rabbit gamma globulin or predominantly against the latter.

In contrast, cells reactive with human gamma globulin were most frequent in the liver tissue and bone marrow of patients with liver disease and macroglobulinaemia respectively.

The authors are indebted to Mr. Domenico Guerra for skilful assistance.

\section{REFERENCES}

Astorga, G., and Bollet, A. J. (1965). Arthr. and Rheum., 8, 511 (Diagnostic specificity and possible pathogenetic significance of inclusions in synovial leucocytes).

Bartfeld, H., and Juliar, J. F. (1964). Lancet, 2, 767 ("Immunological organization" and activity of human peripheral white-blood-cell cultures).

Baum, J., Stastny, P., and Ziff, M. (1964). J. Immunol., 93, 985 (Effects of the rheumatoid factor and antigen-antibody complexes on the vessels of the rat mesentery).

Bonomo, L., and Tursi, A. (1963). Boll. Soc. ital. Biol. sper., 39, 1379 (Studio con il metodo di immuno-fluorescenza della eliminazione di cellule contenenti gammaglobuline e fattore reumatoide nell' espettorato).

- - - and Minerva, V. (1966). J. Path. Bact., 92, 423 (Immunofluorescence study of rheumatoid factor in liver tissue of patients with rheumatoid arthritis and hepatic diseases).

Cohen, S., Ohta, G., Singer, E. J., and Popper, H. (1960). J. exp. Med., 111, 285 (Immunocytochemical study of gamma globulin in liver in hepatitis and postnecrotic cirrhosis).

Delbarre, F., Kahan, A., Amor, B., and Krassinine, G. (1966). C.R. Acad. sci. Paris, Sér. D, 262, 1817 (Sur un leucocyte particulier du liquide synovial: le ragocyte et son intérêt pour le diagnostic des rhumatismes).

Douglas, W. (1965). Ann. rheum. Dis., 24, 40 (The digital artery lesion of rheumatoid arthritis. An immunofluorescent study).

Dumonde, D. C., and Glynn, L. E. (1962). Brit. J. exp. Path., 43, 373 (The production of arthritis in rabbits by an immunological reaction to fibrin). 
Epstein, W. V., and Engleman, E. P. (1959). Arthr. and Rheum., 2, 250 (The relation of the rheumatoid factor content of serum to clinical neurovascular manifestations of rheumatoid arthritis).

Fish, A. J., Michael, A. F., Gewurz, H., and Good, R. A. (1966). Ibid., 9, 267 (Immunopathologic changes in rheumatoid arthritis synovium).

Fostiropoulos, G., Austen, K. F., and Bloch, K. J. (1965). Ibid., 8, 219 (Total hemolytic complement $\left(\mathrm{CH}_{50}\right)$ and second component of complement $\left(\mathrm{C}^{\prime} 2^{h u}\right)$ activity in serum and synovial fluid).

Good, R. A. (1963). Ibid., 6, 479 (In Immunologic aspects of rheumatoid arthritis and systemic lupus erythematosus).

Gough, W. W., and Davis, J. S., IV (1966). Ibid., 9, 555 (Effects of rheumatoid factor on complement levels in vivo).

Hollander, J. L., Fudenberg, H. H., Rawson, A. J., Abelson, N. M., and Torralba, T. P. (1966). Ibid., 9, 675 (Further studies on the pathogenesis of rheumatoid joint inflammation).

—, McCarty, D. J., Astorga, G., and Castro-Murillo, E. (1965). Ann. intern. Med,. 62, 271 (Studies on the pathogenesis of rheumatoid joint inflammation. I. The "R.A. cell" and a working hypothesis).

Kaplan, M. H. (1963). Arthr. and Rheum., 6, 475 (In Immunologic aspects of rheumatoid arthritis and systemic lupus erythematosus).

McCormick, J. N. (1963). Ann. rheum. Dis., 22, 1 (An immunofluorescence study of rheumatoid factor).

Malaguzzi-Valeri, C., and Pipitone, V. (1965). “Atti XII Giornate Reumatologiche Romane”, p. 15. Tipografia Morara Editrice, Roma (Artrite reumatoid e immunità cellulare).

Mellors, R. C. (1963). Arthr. and Rheum., 6, 467 (In Immunologic aspects of rheumatoid arthritis and systemic lupus erythematosus).

—-, Heimer, R., Corcos, J., and Korngold, L. (1959). J. exp. Med., 110, 875 (Cellular origin of rheumatoid factor).

Norton, W. L., and Ziff, M. (1966). Arthr. and Rheum., 9, 589 (Electron microscopic observations on the rheumatoid synovial membrane).

Parker, R. L., and Schmid, F. R. (1962). J. Immunol., 88, 519 (Phagocytosis of particulate complexes of $\gamma$-globulin and rheumatoid factor).

Pernis, B., Ballabio, C. B., and Chiappino, G. (1963). Reumatismo, 15, 187 (Presenza del fattore reumatoide nelle lesioni vascolari in casi di artrite reumatoide aggravata).

Rodman, W. V., Williams, R. C., Jr., Bilka, P. J., and Müller-Eberhard, H. J. (1964). Arthr. and Rheum., 7, 749 (Immunofluorescent localization of beta $1 C$ and beta $1 E$ globulin complement components in synovial tissues from rheumatoid arthritis patients. Abstract).

Schmid, F. R., and Roitt, I. M. (1965). J. Lab. clin. Med., 66, 1019 (Inhibition of complement action by rheumatoid factor).

Scott, J. T., Hourihane, D. O., Doyle, F. H., Steiner, R. E., Laws, J. W., Dixon, A. St. J., and Bywaters, E. G. L. (1961). Ann. rheum. Dis., 20, 224 (Digital arteritis in rheumatoid disease).

Scott, D. G., and Rowell, N. R. (1965). Brit. J. Derm., 77, 211 (Preliminary investigations of arteritic lesions using fluorescent antibody techniques).

Williamson, N., and Ling, N. R. (1965). Ann. rheum. Dis., 24, 513 (Cellular reaction to complexes formed between rheumatoid factor and aggregated human gamma globulin).

Ziff, M. (1965). Ibid., 24, 103 (Some immunologic aspects of the connective tissue diseases).

Zvaifler, N. J., and Bloch, K. J. (1962). Arthr. and Rheum., 5, 127 (Rheumatoid factor-an inhibitor of the complement fixation reaction).

—_ and Pekin, T. J. (1963). Ibid., 6, 308 (Complement components in synovial fluids. Abstract). 
La distribution des facteurs anti-gamma globuline dans la membrane synoviale et dans d'autres tissus au cours de différentes maladies

\section{RÉSUMÉ}

Dans la polyarthrite rhumatoïde on a observé trois tableaux de distribution (clairsemé, lymphoide et vasculaire) des facteurs anti-gamma globuline, détectés par immunofluorescence dans des prélèvements biopsiques de la membrane synoviale. De tels tableaux refléchissaient les altérations histologiques dans la synoviale.

La concentration des facteurs anti-gamma globuline était la plus forte aux lieux principaux du processus morbide, c'est à dire dans la synoviale en l'arthrite, le foie en la maladie hépatique et la moelle osseuse en la macroglobulinémie. On a trouvé aussi ces facteurs dans l'expectoration des malades atteints de bronchite chronique.

On a décelé aussi des facteurs AGG circulants dans le sang de tous ces malades.

Des procédés de coloration mixte avec des fluorochromes spécifiques ont démontré dans la synoviale et dans le foie des cas d'arthrite, des cellules contenant des facteurs actifs contre la gamma globuline humaine agrégée et la gamma globuline de lapin ou principalement contre cette dermière.

Par contre, les cellules qui réagrissaient avec la gamma globuline humaine se trouvaient le plus souvent dans le tissu hépatique et la moelle osseuse des patients atteints de maladie hépatique et de macroglobulinémie respectivement.
La distribución de factores anti-gamma globulina en la membrana sinovial $y$ en otros tejidos en diferentes enfermedades

\section{SUMARIO}

En la poliartritis reumatoide se observaron tres cuadros de distribución (esparcida, linfoide y vascular) de factores anti-gamma globulina (AGGF), detectados por inmunofluorescencia en espécimenes biópsicos de la sinovia. Tales cuadros reflejan alteraciones histológicas en la sinovia.

La concentración de los AGGF fué la mayor en sitios principales del proceso morboso, quiere decir en la sinovia en caso de artritis, en el hígado en caso de enfermedad hepática y en la médula ósea en caso de macroglobulinemia. Se encontraron también estos factores en la expectoración de enfermos con bronquitis crónica.

Se descubrieron también AGGF circulantes en la sangre de todos estos enfermos.

Procedimientos de coloración mixta con fluorocromos específicos demostraron en la sinovia y en el hígado de los casos de artritis células con factores activos contra la gamma globulina humana agregada y la gamma globulina de conejo o principalmente contra la última.

En cambio, células que reaccionan con la gamma globulina humana encontrábanse con la mayor frecuencia en el tejido hepático y en la médula ósea de pacientes con enfermedad hepática o con macroglobulinemia respectivamente. 